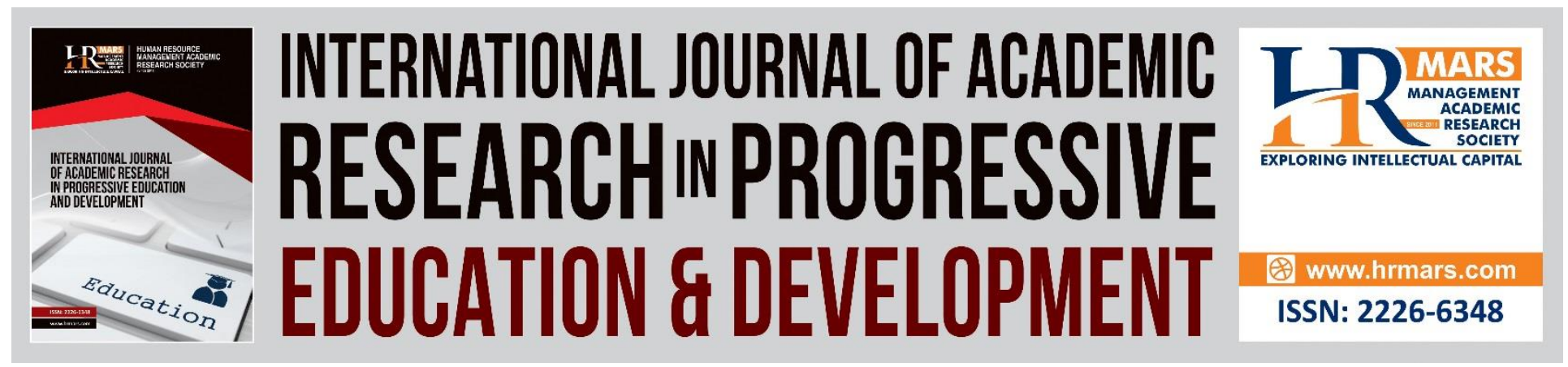

\title{
Motivating Students to Learn: An Overview of Literature in Educational Psychology
}

Saeid Motevalli, Asma Perveen, Mina Tresa Anak Michael

To Link this Article: http://dx.doi.org/10.6007/IJARPED/v9-i3/7779

DOI:10.6007/IJARPED/v9-i3/7779

Received: 11 July 2020, Revised: 23 July 2020, Accepted: 19 August 2020

Published Online: 29 September 2020

In-Text Citation: (Motevalli et al., 2020)

To Cite this Article: Motevalli, S., Perveen, A., \& Michael, M. T. A. (2020). Motivating Students to Learn: An Overview of Literature in Educational Psychology. International Journal of Academic Research in Progressive Education \& Development, 9(3), 63-74.

Copyright: (C) 2020 The Author(s)

Published by Human Resource Management Academic Research Society (www.hrmars.com)

This article is published under the Creative Commons Attribution (CC BY 4.0) license. Anyone may reproduce, distribute, translate and create derivative works of this article (for both commercial and non-commercial purposes), subject to full attribution to the original publication and authors. The full terms of this license may be seen

at: http://creativecommons.org/licences/by/4.0/legalcode

\section{Vol. 9 (3) 2020, Pg. 63 - 74}

Full Terms \& Conditions of access and use can be found at http://hrmars.com/index.php/pages/detail/publication-ethics 


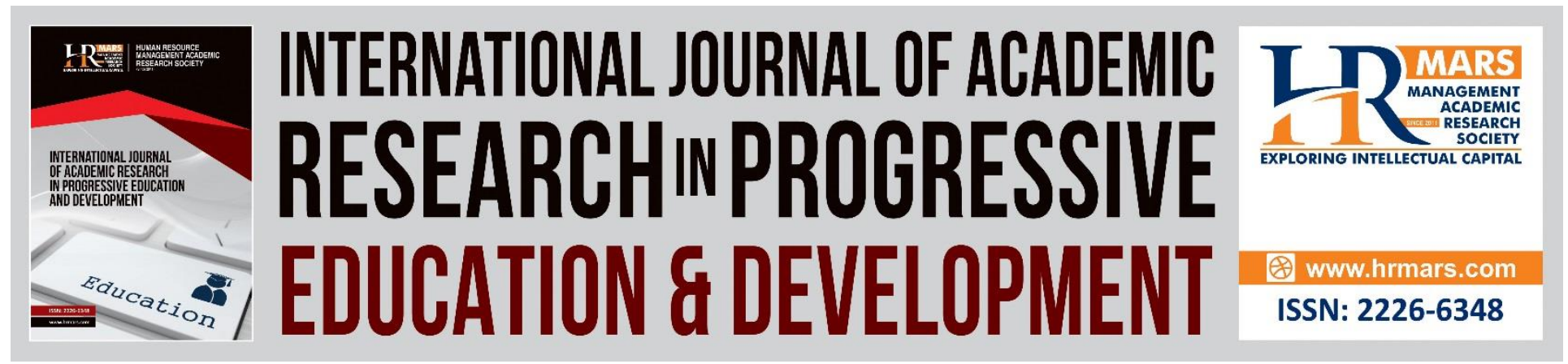

\title{
Motivating Students to Learn: An Overview of Literature in Educational Psychology
}

\author{
Saeid Motevalli, Asma Perveen, Mina Tresa Anak Michael \\ Department of Psychology and Counselling, Faculty of Human Development, Universiti, \\ Pendidikan Sultan Idris, Tanjong Malim, Malaysia \\ Email: saeid@fpm.upsi.edu.my, asmaperveen@fpm.upsi.edu.my, minatresa@gmail.com
}

\begin{abstract}
One of the factors that drive students to gain knowledge and learn new things are motivation. Motivation and learning behaviour are two very important factors in determining students' learning achievement. However, motivation is an abstract thing that is difficult to measure the willingness of students to learn. As such, greater knowledge in motivating student's to learn is needed to help us to understand not only why students are motivated in learning but also ways to help teachers to further maintained student's momentum in engaging with academic activities. This review article aimed to discuss the theories of motivation, highlights about ways to enhance the motivation in students' achievement with some assistants from teachers and other people such as family and friends and how other motivations such as intrinsic and extrinsic motivation can also assist students to stay motivated. In summary, motivation is essential to encourage students to learn in the education system.
\end{abstract}

Keywords: Motivation, Intrinsic Motivation, Extrinsic Motivation, Achievement Motivation, Goal Achievement.

\section{Introduction}

What defines motivation? Motivation is a psychological term where it stems from the desire of wanting something and give fuel as a drive to continue pursuing the desire. Rapiudin (2019) stated that other scholar also agreed that motivation as one of the factor in learning. Some of the scholars have also reinforced and quoted that the reason to do something is often derived from motivation itself (Brown, 2016; Oroujlou, \& Vahedi, 2011; Brodka, \& Parikka, 2019). Scholars have also confirmed that the reason underlies when someone are driven to achieve their goals or getting rewards by using his/her own effort (Covington, 2002; Rapiudin, 2019). There are also some scholars that also believe the expectation of rewards or pleasant consequence that might happen due to their hard work have caused the students to do something or a motivation to do it (Brown, 2016). With regards to psychological perspective, motivation refers to an internal process that activates, guides, and maintains individuals' behaviour over time (Anderman, Gray, 
\& Chang, 2013; Pintrich, 2003; Zimmerman \& Schunk, 2011; Slavin, 2019). In a simple language, motivation can be considered as an eager or attraction that gets you acting, keeps you acting, and determines where you want to go. It is notable to say that motivation can vary in both intensity and direction (Ryan, \& Deci, 2020; Slavin, 2019; Zimmerman \& Schunk, 2011). In summary, motivation is important so that students can continue to engage in learning. Students who are motivated to learn will understand more about their academic performance and continue to improve themselves. Motivation comes in various ways and there is a lot of theories on how people are motivated to do something. Next, we are going to look at some theories of motivation and related it to student's motivation in learning.

\section{Theories of Motivation}

There are some theories of motivation that can help us to understand more about student's motivation in learning. Some of the theories we are going to discuss here are behavioural learning theory, Maslow hierarchy of needs theory, attribution theory, and expectancy theory.

\section{Behavioural Learning Theory}

One of the principle in behavioural learning theory are reward and reinforcement. Reinforcement learning method have been applied by a lot of educators to help students to continue to be motivated in learning. Some of the reward and reinforcement method we can see nowadays in education system are adapting games and quizzes in academic activities. One of the recent study by Silva, Rodrigues, \& Leal, (2019) reported that creating an educational games into curriculum activities may reduce their boredom factor in the classroom which in turn, increase students' motivation and interest to learn. In this article, Silva and his colleague wanted to determine whether gamified resources which are called Accountingame and Marketingame that will help to increase the performance of the sample of the study, 816 Portugese undergraduates that attend Accounting and 195 students that attend Marketing. Characteristic of the game such as Concentration, Clarity and other characteristic are looked into to see their direct effects in student's learning. Despite its encouraging results as noted by Silva et al., they also suggest that traditional teaching method if handled properly by educators is still essential in student's learning. (Silva, Rodrigues, \& Leal, 2019). There are some reasons why students become willing to engage in learning while playing games but we will not further discuss it as we admit that it's just our assumptions and it could be derives from other theory such as biological theory.

When an individual enters a state of profound absorption in a certain activity that is intrinsically pleasant - like when an artist goes on stage or an athlete takes part in a competition and both focus on achieving an excellent performance - it is called flow (Csikszentmihalyi, 1990). The flow theory is based on the relationship between the challenges individuals are faced with and the skills they must have to successfully accomplish certain activities. This balance between challenges and skills is quite fragile, and likely to cause apathy, when both challenges and skills are low; anxiety, when challenges are high and skills are low; and boredom, when both challenges and skills are high (Csikszentmihalyi, 1996). In view of the three mentioned possibilities, it is up to the teacher to adjust the levels of demand through adequate strategies which allow for a balance between skills and challenges, thus avoiding the emerging of feelings that may hinder students from reaching a state of flow as far as learning is concerned (van de Pol, Volman, \& 
Beishuizen, 2010). Because the flow is intrinsically rewarding, students look forward to experiencing it so that they can develop new skills that will allow them to grow and ensure academic achievement (Nakamura \& Csikszentmihalyi, 2009). Moreover, the experience of flow and emotional engagement in the gamified learning setting had a highly significant impact on motivation. In addition, the results show that flow and emotional engagement explained $68 \%$ of variance of motivation; flow, emotional engagement, and motivation explained $22 \%$ of variance of academic success (Ozhan, \& Kocadere, 2020).

\section{Maslow Hierarchy of Needs}

Maslow theory also plays a role in helping educators to understand more about student's motivation. Robbins \& Judge mentioned that "Maslow perceived that basically a person will generally be driven to act not only because of the external factor, but mainly because he or she has a need to be fulfilled" (Robbins \& Judge in 2013, p. 203). According to Maslow, there are 5 stages that are needed to fulfilled human needs which are physiological needs, safety, social, esteem and self-actualization. A research conducted by Rapiudin (2019) that study about student's perception on their motivation in learning English based on Maslow concept found out that most students understand the importance of learning. In this study, the samples which consist of 50 language students reported that their motivational need in learning language are related to some of the Maslow concept such as to fulfil their insecurity, self-esteem and achieving self-actualization needs. However, the students also indicated that learning especially learning foreign language was used as a mere instrumental in their life and not for integrative one as noted by Alptekin (2002), such as to find better job or advance their career. While students considered that learning such as learning foreign language is important for them, they also regarded that other skills than learning is also important for them to achieve their dreams and self-actualization needs. In conclusion, we can conclude that based on this finding, students are motivated to learn when they have deficiency needs and growth needs to understand something according to Maslow's theory. However, it is also important to note that a powerful instrument for long-time learning is needed to trigger a student's motivation to study and learn. Maslow's concept can be used on the base of students' need so that the specific service given to the students can be clearly predicted. If the students' need can be clearly described, then the future of training or learning can be specifically tailored based on the students' demand, thus leading to a more effective process.

\section{Attribution Theory}

Students constantly received feedback regarding their academic performance or other task in the classroom. Regardless of the task, the feedback will influence the student's mindset and thus also influence their motivation in learning. One of the theories that can explain why this struggle of explanation happened among students achievement is attribution theory. Mudavadi (2019) noted that in 1972, Weiner underlies both attribution theory by Fritz Heider (1958) and locus of control theory by Julian Rotter (1966) and developed his Theory of Attribution of Learning. The theory helps to explain how students perceive their success and failures with others in terms of causes and attributions. Weiner also noted that students may include things such as intelligence, illness, instructional bias and mood as their success or failure. Mudavadi (2019) also reported 
that in their study the results shows students who have more positive attribution perspective are more likely hold onto their academic versus being academically dismissed at the end of probationary semester when they take responsibility of their success or failure. Attribution theory is important so that educators can enhanced their understanding in student's perception about their feedback on academic performance. Educators should tried to make use this theory by giving them feedback based on their efforts, which is something that the students can controlled rather than their innate ability or luck. Not only constructive criticism can help to improve their shame resilience but it also improve their academic perspective in learning with their efforts.

\section{Expectancy Theory}

Expectancy theory refers to the theory of motivation regarding beliefs that individuals' attempts to achieve depend on their expectations of reward. Atkinson (1964) presented this theory based on the following formula:

Motivation $(\mathrm{M})=$ Perceived probability of success $(\mathrm{Ps}) \times$ Incentive value of success (Is).

Students have expectations. However, in order to achieve those expectations, students should give efforts regardless of any form. In short, students are motivated when their chances of success is high or when they place value in their expectations. According to expectancy-value theory, it was also hypothesized that expectancy and value can also cause achievement-related behaviour such winning an award. Specific studies or achievement valued by students will caused stronger effect of expectancy in their motivation to learn (Loh, 2019). From here, it can be seen that expectancy theory can influenced student's motivation by perceiving the probability of success. However, it is also important to note that this theory is multiplicative. For example, if students perceived their probability of success is zero, then their motivation is also equal to zero. Therefore, an optimal amount of probability perceived by students is crucial to maintain their motivation. There have been some studies that have conducted the relationship between the expectancy value theory and students motivation in learning (Corwyn, \& McGarry, 2020; Eccles, \& Wigfield, 2020; Schnettler, Bobe, Scheunemann, Fries, \& Grunschel, 2020). Although the recent findings are more to experimental research, these findings proved that students are motivated when the probability of success in academic is possible although it is not easy to achieve (Lee, \& Hall, 2020; Schunk, \& DiBenedetto, 2020; Weiner, 2010).

In summary, educators should tried to set a grading where all students can reflect their effort when they are being assigned to a task without decreasing their motivation.

\section{How to Enhance Achievement Motivation}

In previous discussions, the theory of motivation was indicated that how some findings can contribute to understand the connectivity of the theory and student's motivation in learning. First, we will introduce the definition of achievement motivation. Next, we are going to discuss some of the methods to enhanced achievement motivation in student by reviewing some of the recent researches on achievement motivation and student's goal. In the next session, we will further discuss about teacher's expectations and achievement motivation. In every section, we will included how teachers or educators can help the students to overcome and approach the problem to stay motivated in learning. 
INTERNATIONAL JOURNAL OF ACADEMIC RESEARCH IN PROGRESSIVE EDUCATION AND

DEVELOPMENT

Vol. 9, No. 3, 2020, E-ISSN: $2226-6348 @ 2020$ HRMARS

\section{Achievement Motivation}

Achievement motivation, the generalized tendency to attempt for success and to choose goaloriented success/failure activities, is one of the types of motivation for education that can also help students to stay motivated in education (Schunk, \& Dibenedetto, 2016; Zimmerman \& Schunk, 2011). Achievement motivation also can be defined as a drive that determines the cognitive, emotional and behavioural aspects of students' attachment to the educational process (Bakadorova, \& Raufelder, 2020). Smith, Karaman, Balkin \& Talwar (2019) noted that the standard of excellence and competition can resulted achievement motivation by using performance evaluation. In other words, it is a form of motivation satisfying high standards of performance which is characterized by a competitive drive" (pg 2, Jennet, 2008 in Smith et. al, 2019). It can also be defined as by increasing individual's effort in all activities where these activities can also help to reflect the individual's perspective of excellence. Moreover, "achievement motivation also consists of various and complex evaluations, estimates, inferences, values, standards, set of assumptions and emotional reactions that may be unreasonable, flawed, and contradictory." (pg 2, Dweck \& Elliot, 1983 in Smith et al., 2019).

\section{Student's Goals and Motivation}

Students are motivated when they have goals. Some researchers have noted that for 50 years, there are extensive studies ranging around 1000 have concluded that performance was increased by goals and that employee performance in a company decreased when the goals are removed or lowered (Welsh, Bush, Thiel, \& Bonner, 2019; Locke, \& Latham, 2015). However, aside from employee, what are the type of goals that students want to achieve? Dweck \& Leggett in 1988 by using achievement goal theory have proposed that there are two primary types of goals from an orientation perspective. For the first type goal, individuals may have learning goals, or goals for the sake of learning and self-improvement. This goal motivationally oriented toward learning goals and called task or mastery goals. The second type of goals explained that individuals may have outcome goals, or goals to demonstrate competence by meeting an external standard. This goal motivationally oriented toward performance goals (Wentzel \& Brophy, 2014; Givens Rolland, 2012; Senko, Hulleman, \& Harackiewicz, 2011). Students with learning goals consider the main goals and objectives of tutoring in order to achieve the competence in the skills being educated, while students with performance and goals basically attempt to enhance positive judgments of their capability and also keep away from negative judgments. Students who are endeavoring toward learning goals are probably going to take difficult projects and courses and to look for challenges and difficulties. Conversely, students with performance goals concentrate on obtaining good marks, taking simple and easy courses, and avoiding difficult and challenging circumstances (Urdan \& Mestas, 2006). Goal achievement was emphasized in outcome goals for the sake of accomplishing an external achievement and, thus, emphasize the consequences. However, in learning goals, it was more on self-improvement and personal growth which emphasized on higher possible goals which in turn also stress on the process in achieving goals. (Welsh et al., 2019). However, goals that required high demands will cause students to have low self-esteem as they perceive they are incapable to reach the goal. The students will also likely to adopt unethical behaviours such as cheating in their test or task to gain their goals. In short, we suggest that it is important for teachers to let students have learning goals instead of 
performance-oriented goals. This is because students will try to learn not for the sake of extrinsic motivation such as grades or performance but for intrinsic motivation such as for their interest or self-improvement. Teachers can help students to develop their learning goals by allowing students to have the freedom to make choice with their learning.

\section{Teacher's Expectation and Motivation}

Some researches on teachers' expectations for their students have mostly endorsed that students behave on the base of their teachers' expectations (explicit expectations and implicit prejudiced attitudes) from them (Hinnant, O'Brien, \& Ghazarian, 2009; Peterson, Rubie-Davies, Osborne, \& Sibley, 2016), predominantly in early school years and when teachers know relatively little about their students' actual achievement levels and these expectations can be considered as reliable predictors of the future students' academic achievement. According to the recent study conducted by Heyder and colleagues (2020), although their research is more about student's intrinsic motivation rather than achievement motivation, the results show that teachers who reported that their belief that math requires innate ability will cause low achieving students to have lower intrinsic motivation. These results suggest that teachers' beliefs that math success depends on innate ability may be an important obstacle to creating a classroom atmosphere that fosters engagement and learning for all students (Heyder, Weidinger, Cimpian, $\&$ Steinmayr, 2020). At here, this findings also suggest that teachers are also one of the key that can help to increase or decrease students' motivation in learning. However, further research are still required to determine whether students' achievement motivation will be influenced by teachers' expectations. How can teachers help their students with their expectations? One of the ways are giving autonomous support to the students. First of all, teachers need to be assertive and change their ways when giving autonomous support to students. There are some researches that discussed how teachers as autonomy supporter should help. Ryan and Deci (2020) noted that teachers who give more autonomous support are the type that listen more, responsive towards students, bringing students' attention about their interests, giving more support towards students' capability and convey more understanding towards students' opinion. Not only the behaviour give advantages to the teachers but also increase students' motivation.

\section{Students' Intrinsic and Extrinsic Motivation}

Sometimes, there are some students that are willing to learn a subject without caring what the benefits or incentives that they will get in that learning process. We are going to discuss about what are the other means that help students to stay motivated throughout their learning process. There are some motivations that can help students to stay motivated which are intrinsic and extrinsic motivation.

\section{Intrinsic Motivation}

What is intrinsic motivation? Uno (2012);Tokan and Imakulata (2019) suggested that individual act was drive from motivation within an individual. There are also that suggested intrinsic motivation as an encouragement that comes from within which leads to satisfaction and intrinsically motivated students are more engaged, retain information better, and are generally happier than other students (Deci, \& Ryan, 2010; Hanus, \& Fox, 2015; Tokan, \& Imakulata, 2019). 
According to Ryan and Deci (2020), intrinsic motivation benefits are shown within formal education. A meta-analysis conducted by Taylor et al (2014) reported that there is a significant relationship between intrinsic motivation and school achievement. The meta-analysis was studied on high school and college students in Canada and Sweden and the results reported that the higher the intrinsic motivation, the higher the performance and thus become one of the outline in student's achievement. In addition, Froiland and Worrell (2016) also reported that student's engagement can be predicted by intrinsic motivation, which they reported help to also predicted their achievement in GPA. The results was consistent when the analysis was limited to African American and Latino students as their sample (Ryan, \& Deci, 2020). There are also other study conducted by Tokan and Imakulata (2019) to determine the effect of motivation and students' learning behaviour on student's achievement as well as the direct effect of intrinsic and extrinsic motivation and learning behavioral on learning achievement of the biology education department students in University of Nusa Cendana. The information was collected by using questionnaire and a document of sample's learning achievement. The study reported that learning behaviour was influenced by intrinsic motivation. It is also reported that based on the results, when the intrinsic motivation increases, the student's learning behaviour also increases. This study also supported the evidence that intrinsic motivation have influence on students' achievement and learning behaviour (Tokan, \& Imakulata, 2019). Besides, the results showed that motivation as an essential study skills can assist students' academic achievement and learning (Motevalli, Roslan, Sulaiman, Hamzah, Hassan, \& Garmjani, 2013). Moreover, it has been demonstrated in the literature that compared to extrinsically motivated students, those who are intrinsically motivated are more likely to persist when facing learning challenges (Huang, 2011; Liao, Chen, \& Shih, 2019).

\section{Extrinsic Motivation}

Extrinsic motivation was often contrasted with intrinsic motivation, where the behaviours is done due to external reward or for reasons and not for self-satisfaction. According to Ryan and Deci (2020), from self-determination theory view, extrinsic motivation is divided into four major subtypes which are external regulation, introjection, identification and integration. Here are example of the figure how intrinsic motivation and 4 subtypes of extrinsic motivation is portrayed (see figure 1). 
Vol. 9, No. 3, 2020, E-ISSN: $2226-6348$ @ 2020 HRMARS

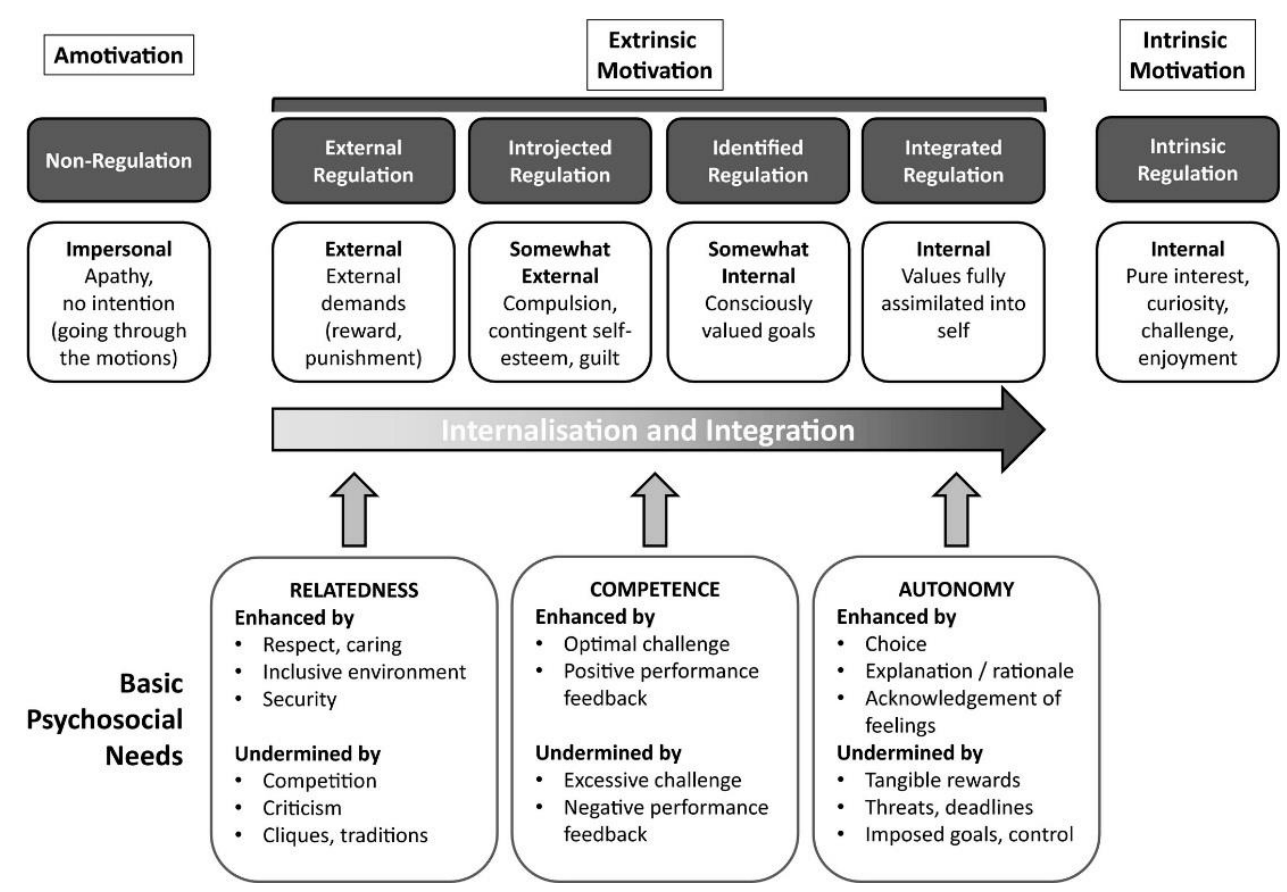

Figure 1: Self Determination Theory's Taxonomy of Motivation. This is adapted from Ryan and Deci's theory.

However, study conducted by Tokan and Imakulata (2019) on students of University of Nusa Cendana reported that students learning behaviour was not affected by extrinsic motivated. The researchers suggested that corrective action is needed so that extrinsic motivation can also play a part in student's learning behaviour. The researchers suggest factors such as effective strategies, models, methods and learning should be applied to enhance the extrinsic motivation among students (Tokan, \& Imakulata, 2019).

\section{Implications and Conclusions}

This review article showed that educators and teachers can make used of the theory such as behavioural learning theory, Maslow theory, attribution theory and expectancy theory in their teaching to make students to be motivated and stay engaged with their academic learning. Besides, this review article also stated some of the possible ways that can be applied in their teaching for each theory. It also further discuss other motivational ways that can be used for students in other session in how to enhance achievement motivation. The review article also discussed about how student's intrinsic and extrinsic motivation can influence them to learn. This article review also suggest that the findings show that student's psychological need is also as important as student's physical health in education system. Students have the right to decide on how to learn in their life and required positive support from their teachers, family and friends to stay motivated. We hope that this review article can also help to shade some lights that teachers' psychological need should be given an opportunity so that students can be more motivated in learning the materials. Although each students are different from one another, various techniques have been invented to encourage them to learn. What matters the most in the end is 
INTERNATIONAL JOURNAL OF ACADEMIC RESEARCH IN PROGRESSIVE EDUCATION AND

DEVELOPMENT

Vol. 9, No. 3, 2020, E-ISSN: $2226-6348$ @ 2020 HRMARS

their perception in learning. If the students are willing to change their perception and mindset in learning, a lifelong of education and success will surely be achieved.

\section{Corresponding Author}

Saeid Motevalli

Department of Psychology and Counselling, Faculty of Human Development, Universiti

Pendidikan Sultan Idris, Tanjong Malim, Malaysia

Email: saeid@fpm.upsi.edu.my

\section{References}

Alptekin, C. (2002). Towards intercultural communicative competence in ELT. ELT journal, 56(1), 57-64.

Anderman, E., Gray, D., \& Chang, Y. (2013). Motivation and classroom learning. In W. Reynolds, G. Miller, \&I. Weiner (Eds.) Handbook of psychology (Vol. 7, 2nd ed., pp. 99-116). Hoboken, NJ: Wiley.

Atkinson, J. W. (1964). An introduction to motivation.

Brodka, P., \& Parikka, L. (2019). Motivation to Study Social Services in Higher Education: Case: Laurea University of Applied Sciences.

Bakadorova, O., \& Raufelder, D. (2020). The relationship of school self-concept, goal orientations and achievement during adolescence. Self and Identity, 19(2), 235-249.

Brown, H. D. (2016). Teaching by principles: An Interactive Approach to Language Pedagogy.

Corwyn, R. F., \& McGarry, P. P. (2020). AN EXPECTANCY VALUE THEORY PREDICTS ACHIEVEMENT IN UNDERGRADUATE STATISTICS THROUGH ACADEMIC DELAY OF GRATIFICATION4. Statistics Education Research Journal, 19(2).

Covington, M. V. (2002). Rewards and intrinsic motivation. Academic motivation of adolescents, 169-192.

Csikszentmihalyi, M. (1990). The domain of creativity. In M. A. Runco \& R. S. Albert (Eds.), Sage focus editions, Vol. 115. Theories of creativity (p. 190-212). Sage Publications, Inc.

Csikszentmihalyi, M. (1996). Flow and the psychology of discovery and invention (Vol. 56, p. 107). New York: Harper Collins.

Deci, E. L., \& Ryan, R. M. (2010). Intrinsic motivation. The corsini encyclopedia of psychology, 12.

Dweck, C. S., \& Leggett, E. L. (1988). A social-cognitive approach to motivation and personality. Psychological review, 95(2), 256.

Eccles, J. S., \& Wigfield, A. (2020). From expectancy-value theory to situated expectancy-value theory: A developmental, social cognitive, and sociocultural perspective on motivation. Contemporary Educational Psychology, 101859.

Froiland, J. M., \& Worrell, F. C. (2016). Intrinsic motivation, learning goals, engagement, and achievement in a diverse high school. Psychology in the Schools, 53(3), 321-336.

Huang, W. H. (2011). Evaluating learners' motivational and cognitive processing in an online game-based learning environment. Computers in Human Behavior, 27(2), 694-704. 
INTERNATIONAL JOURNAL OF ACADEMIC RESEARCH IN PROGRESSIVE EDUCATION AND

DEVELOPMENT

Vol. 9, No. 3, 2020, E-ISSN: $2226-6348$ @ 2020 HRMARS

Hanus, M. D., \& Fox, J. (2015). Assessing the effects of gamification in the classroom: A longitudinal study on intrinsic motivation, social comparison, satisfaction, effort, and academic performance. Computers \& education, 80, 152-161.

Heyder, A., Weidinger, A. F., Cimpian, A., \& Steinmayr, R. (2020). Teachers' belief that math requires innate ability predicts lower intrinsic motivation among low-achieving students. Learning and Instruction, 65, 101220.

Hinnant, J. B., O'Brien, M., \& Ghazarian, S. R. (2009). The longitudinal relations of teacher expectations to achievement in the early school years. Journal of educational psychology, 101(3), 662.

Lee, S. Y., \& Hall, N. C. (2020). Understanding Procrastination in First-Year Undergraduates: An Application of Attribution Theory. Social Sciences, 9(8), 136.

Liao, C. W., Chen, C. H., \& Shih, S. J. (2019). The interactivity of video and collaboration for learning achievement, intrinsic motivation, cognitive load, and behavior patterns in a digital game-based learning environment. Computers \& Education, 133, 43-55.

Locke, E. A., \& Latham, G. (2015). Goal-setting theory. Organizational behavior, 1, 159-183.

Loh, E. K. (2019). What we know about expectancy-value theory, and how it helps to design a sustained motivating learning environment. System, 86, 102119.

Motevalli, S., Roslan, S. B., Sulaiman, T., Hamzah, S. G., Hassan, N. C., \& Garmjani, M. G. (2013). New study skills training intervention for students who suffer from test anxiety. Asian Social Science, 9(7), 85.

Mudavadi, K. C. (2019). Newspaper Framing of a Health Crisis and Public Perception in Kenya: The Case of Kenyatta National Hospital Wrong-Patient Brain Surgery (Doctoral dissertation, United States International University-Africa).

Nakamura, J., \& Csikszentmihalyi, M. (2009). Flow theory and research. Handbook of positive psychology, 195-206.

Oroujlou, N., \& Vahedi, M. (2011). Motivation, attitude, and language learning. Procedia-Social and Behavioral Sciences, 29, 994-1000.

Ozhan, S. C., \& Kocadere, S. A. (2020). The effects of flow, emotional engagement, and motivation on success in a gamified online learning environment. Journal of Educational Computing Research, 57(8), 2006-2031.

Peterson, E. R., Rubie-Davies, C., Osborne, D., \& Sibley, C. (2016). Teachers' explicit expectations and implicit prejudiced attitudes to educational achievement: Relations with student achievement and the ethnic achievement gap. Learning and Instruction, 42, 123-140.

Pintrich, P. R. (2003). Motivation and classroom learning. Handbook of psychology, 103-122.

Rapiudin, A. U. (2019). Students' Perception on Their Motivation in Learning English (The Analysis Students' Motivation Based on Maslow's Concept). Biormatika: Jurnal ilmiah fakultas keguruan dan ilmu pendidikan, 5(02), 155-160.

Robbins, S. P., \& Judge, T. A. (2013). Organizational Behavior.(S. Yagan, Ed.).

Ryan, R. M., \& Deci, E. L. (2020). Intrinsic and extrinsic motivation from a self-determination theory perspective: Definitions, theory, practices, and future directions. Contemporary Educational Psychology, 101860. 
INTERNATIONAL JOURNAL OF ACADEMIC RESEARCH IN PROGRESSIVE EDUCATION AND

DEVELOPMENT

Vol. 9, No. 3, 2020, E-ISSN: $2226-6348$ @ 2020 HRMARS

Senko, C., Hulleman, C. S., \& Harackiewicz, J. M. (2011). Achievement goal theory at the crossroads: Old controversies, current challenges, and new directions. Educational psychologist, 46(1), 26-47.

Schnettler, T., Bobe, J., Scheunemann, A., Fries, S., \& Grunschel, C. (2020). Is it still worth it? Applying expectancy-value theory to investigate the intraindividual motivational process of forming intentions to drop out from university. Motivation and Emotion, 1-17.

Schunk, D. H., \& Dibenedetto, M. K. (2016). Self-efficacy theory in education. Handbook of motivation at school, 2, 34-54.

Schunk, D. H., \& DiBenedetto, M. K. (2020). Motivation and social cognitive theory. Contemporary Educational Psychology, 60, 101832.

Slavin, R. E. (2019). Educational psychology: Theory and practice.

Silva, R., Rodrigues, R., \& Leal, C. (2019). Play it again: how game-based learning improves flow in Accounting and Marketing education. Accounting Education, 28(5), 484-507.

Smith, R. L., Karaman, M. A., Balkin, R. S., \& Talwar, S. (2020). Psychometric properties and factor analyses of the achievement motivation measure. British Journal of Guidance \& Counselling, 48(3), 418-429.

Taylor, G., Jungert, T., Mageau, G. A., Schattke, K., Dedic, H., Rosenfield, S., \& Koestner, R. (2014). A self-determination theory approach to predicting school achievement over time: The unique role of intrinsic motivation. Contemporary Educational Psychology, 39(4), 342-358.

Tokan, M. K., \& Imakulata, M. M. (2019). The effect of motivation and learning behaviour on student achievement. South African Journal of Education, 39(1).

Urdan, T., \& Mestas, M. (2006). The goals behind performance goals. Journal of educational psychology, 98(2), 354.

Van de Pol, J., Volman, M., \& Beishuizen, J. (2010). Scaffolding in teacher-student interaction: A decade of research. Educational psychology review, 22(3), 271-296.

Welsh, D., Bush, J., Thiel, C., \& Bonner, J. (2019). Reconceptualizing goal setting's dark side: The ethical consequences of learning versus outcome goals. Organizational behavior and human decision processes, 150, 14-27.

Weiner, B. (2010). The development of an attribution-based theory of motivation: A history of ideas. Educational psychologist, 45(1), 28-36.

Wentzel, K. R., \& Brophy, J. (2014). Motivating students to learn (4 ${ }^{\text {th }}$ ed.). New York, NY: Routledge.

Zimmerman, B. J., \& Schunk, D. H. (Eds.) (2011). Handbook of selfregulation of learning and performance. New York, NY: Routledge. 